\title{
A Review of The Unethical Business Practices That Causes Loan Default in Small Scale Enterprises in Port Loko Municipality in Sierra Leone
}

\author{
Edmund Benedict Amara \\ Ph.D. in Management, Texila American University, Port Loko, Sierra Leone, West Africa
}

\begin{abstract}
Small scale enterprises are an income stream for the unemployed and under-employed in Sierra Leone. The financing of such a venture is from the loan capital of Micro Finance Institutions and other credit agencies in the country. Default in the repayment of loan capital within prescribed conditions has been an issue because of the unethical practices of lenders and borrowers and hence concern for studies. The primary objective of the study is to do a review on the unethical business practices that causes loan default in small-scale enterprises in Port Loko municipality in Sierra Leone. Such studies will avail recommendations that shall be instruments to minimize the rate of unethical practices of borrowers and lenders within the Pot Loko Municipality. The Specific objectives of the study are to know the attitudes of Lenders and borrowers that influence loan default. Questionnaires were administered to respond to Researched Questions which were framed from the research objectives. Also, Reviews of others writers were done with regard ethical issues. The researcher Used the Likert Scale in preparing and administering the questionnaire. Opinions of Respondents were analyzed using the Structured Package for Social Sciences. The following analyses were done: i) Percentage Analysis, ii) Analysis of correlation by use of the Pearson Correlation. iii). Analysis of coefficient iv) Analysis of Model summary v) Analysis of Anova. From the study, the Researcher discovered that Unethical business practices like bribe-taking and other dishonest games are predominant between lenders and borrowers, and these practices have greatly influenced loan default in small-scale enterprises in Port|Loko Municipality in Sierra Leone and have a significant relationship on loan default.
\end{abstract}

Keywords: Loan Default, Small Scale Businesses, Unethical.

\section{Introduction of the Study}

Ethical business practices make the going concern of business a possibility. Many businesses have folded because of unethical business practices. Laura Holton explains that maintaining business success is always a challenge the resource of committed employees. There are expected pressures on organizations despite their size. In a further submission, Laura revealed that in the midst of pressure, some businesses might choose to work harder, and others may turn to unethical business practices. She, therefore, submitted that unethical business practices encompass anything that falls below minimum standards for business code of conduct. This includes any behavior that is widely accepted as being morally wrong and leads to the mistreatment of people, animals, or the environment.

The above review presents that there are unethical businesses practices. Such practices are seen be those generally unaccepted in our settings. Organizations both small, medium, and large may suffer from ethical issues.

Credit Agencies as organizations have codes and conduct. The process of loan disbursement follows and morally designed order. Set down codes and guiding principles for both the borrow and lender. Lenders sign in Job 
contracts and are given terms of reference. Borrowers are also given loan contracts before disbursement. These laws servers as foundations for ethical procedures in the process of loan portfolio delivery. Adherence to designed credit policies by both lenders and borrows will help minimize the high rate of loan default that occurs in organizations that follow unethical business practices.

This publication is to present a review on the unethical business practices that causes loan default in small enterprises in the Port Loko Municipality in Sierra Leone. The work shall look at both the attitudes of Lenders and borrowers that cause loan default.

\section{Problem Statement}

Unethical practices by both lenders and borrowers are problems that cause loan default. The borrower suffers default consequences either by losing personal properties, closure of business, or is faced with the consequences of the law. On the other hand, the lender suffers a high rate of default and hence a reduction on profitability and putting the portfolio at risk.

Generally, the loan default caused either by the lender or the borrower may have an impact on the employment rate in the country and have a reduction on the revenue raised within the country.

\section{Justification of the Study}

There is an adverse effect of loan default on lenders and borrowers. The unethical business practices of both lenders and borrowers are worth investigating. Research work will help avail information to managements of Credit agencies of the unethical attitude of some credit staff that prompts default. It will create awareness for monitoring not only the borrowers but some of the credit agents on the field and in offices. This will reduce or minimize the high rate of default amongst borrowers. It will promote a good way of doing business and hence promote the going concern of both credit agencies and small-scale businesses in Sierra Leone.

Finally, it will serve as a resource material for those in the field of Business ethics and credit management.

\section{Research Objectives}

The primary objective of the study is to do a review on the unethical business practices that causes loan default in small-scale enterprises in Port Loko municipality in Sierra Leone.

The following are the Specific objectives of the study:

1. To know the attitudes of Lenders that influence loan default?

2. To know the attitudes of Borrowers that influence loan default?

\section{Research Questions}

1. Are there lender's attitude that influence loan default?

2. Are there Borrower's attitude that influences loan default?

\section{Research Hypothesis}

H1 - There are Leaders attitudes that influences loan default

$\mathrm{H} 2$ - There are Borrowers attitude that influences loan default.

\section{Managerial Implication}

The management of both small-scale businesses and credit agencies plays a vital role in the issue of loan capital. The credit agencies provide the loan capital, and the small-scale businesses use the loan capital and make repayment with specified conditions. However, unethical businesses practices will negatively affect both operations. The loan portfolio of the credit agencies will be at risk with default issues. This will lead to bad debt problems that will adversely affect profitability, and hence the operation of both the credit agencies and smallscale enterprises will be undermined. The goodwill of both the lender and borrower will be impaired because of unethical issues. Finally, the going concern of both operations 
will be negatively affected because of the effect of the default resulting from unethical issues that will also hinder operations because of cash flow issues.

\section{Scope For Further Research}

The study on the review of the unethical business practices that causes loan default in small-scale enterprises in Port Loko Municipality in Sierra Leone avails opinions expressed by respondents with regards to unethical issues leading to loan default. Further studies shall be tailored to know the reasons for such unethical practices by both borrowers and lenders in the implementation process. This will help credit agencies to make appropriate managerial decisions that will minimize unethical practices in the implementation process. This shall also increase the morale of both borrowers and lenders and hence the increase in profitability and the attainment of going concern.

\section{Literature Review}

Small scale enterprises have got a pivotal role in the development of a country. A study examined small businesses as a dynamic engine for the growth of countries' economies [1]. They play a greater role towards unemployment reduction and hence contribute towards the gross Domestic Product of a country.

These small-scale enterprises require capital for operation. A review proves capital as whatever that brings value or benefit to its owner [2]. Capital acquisition is a difficult issue for small-scale businesses. In a study, it was shown that Capital acquisition is a big problem for private businesses [3]. This has led many to acquire capital from Micro Finance Institutions. Leon's output of a study presents Micro Finance as one of the poverty reduction strategies in the world [4]. The provision of small-scale loans to business owners has aided their development and existence. Micro Finance Institutions are Financial Lenders. Their lending pattern is not much based on capital. In the study of [5], it is disclosed that the poverty eradication goal will not be accomplished if Micro Finance Institutions enforces issues of Collateral. A study on collateral defines collateral as an asset that is accepted by a lender for a loan [6]. If collateral is accepted, most borrowers will go without a loan because of the poverty nature of our country. However, Lenders put on professional practices to secure their loan portfolio.

Loan portfolio security is very important for lenders. According to [7], a loan portfolio is a loan that a lender is owed. In addition, [7] highlighted the component of loan portfolio as principal and interest in the hands of the borrowers. This portfolio can only be secured in the midst of ethical business operations.

Ethics plays a very vital role in the existence of individuals, groups, communities, and organizations. The work of [8] revealed that the concept of business ethics began in the 1960s. During this time [8] added, corporations became more aware of a rising consumer-based and society had shown concerns regarding the environment, social causes, and corporate responsibility. In addition, [8] examined that the concept of business ethics evolved and goes beyond just the moral code of right and wrong but attempts to reconcile what companies must do legally as against maintaining a competitive advantage over other businesses. [8] therefore viewed business ethics as the study of appropriate business policies and practices regarding potentially controversial subjects including corporate governance, insider trading, bribery, discrimination, corporate social responsibility, and fiduciary responsibilities. In addition, [8] submitted that the laws often set a tone and guide business ethics and business ethics provide a basic guideline that businesses can choose to follow to gain public approval.

Businesses should be based on sound ethical principles. The ethical structure of the business will attract prospective investors. In a study, an investor is defined as a person who commits 
capital in expectation of receiving financial returns [9].

We can see that there are financial returns for a business undertaken, and therefore, they must be ethically handled to attract customers and gain continuity. The study of [10] shows that business ethics can be examined from various perspectives. In addition, [10] pointed out that the enterprise, employees, and society have various perspectives of business ethics. Further, [10] defined Ethics as a process of evaluating actions according to moral principles or values, and that Ethical issue concerns fairness, justice, rightness, or wrongness.

Submissions with regards business ethic make us to know that there are generally accepted practices to adopt to be successful in business operation. The going concern of business organizations is not only tied to cash but also compliance to operational and widely accepted practices. A financial disclosure defines the going concern as part of the General Acceptable Accounting Practice, and that going concern is the ability of an entity to operate such that it will be able to realize its assets and meet its obligations during the course of business operation [11].

The going concern of credit organizations cannot be met if dishonest clients divert loans for other motives. In a study it funds is defined fund diversion is defined as mis-utilization of fund for purpose of which loan was not sanctioned [12].

There are two parts of credit lending schemes. These parts show the responsibility of the lender and the borrower. Therefore, credit agencies administer a loan agreement before issuing loans to borrowers. In a study loan agreement as a formal contract and an important relationship between lenders and borrowers [13]. This contract in an ethical business operation will minimize loan default. In the research work of [14], defaulting on a loan simply means that there is a failure to do adequate payments with a particular time. Further, in addition, [14] submits that for a loan to be in default, there should be a failure to comply with loan terms in the loan contract to do repayment of a loan. Such a situation, as revealed by her studies, is very serious and can affect both the lender and borrower. Therefore, an understanding of the terms of the loan by borrowers is a remedy in her studies to avoid defaulting.

The lender's attitude in business operation counts for the success of the venture. Unethical workers dwindle a business, and these practices are dishonest and corrupt in nature. A study examined the unethical behavior of workers of credit organizations as Not Providing Correct information, Over promoting, Seducing customers to take more Loan [16].

Sierra Leone is disadvantageous and very poor despite the wealth of natural resource deposits. It is confirmed in a study that Sierra Leone is amongst the poor countries in the world [17].

One of the ways to alleviate poverty is the involvement of all to be a responsible citizen to accept developmental programs. In a study, it is presented that Helping the poor countries is an important part of western development policy aid policy [17]. Disclosed policy [17] is based on the assumption that poor countries lack capital and a better financial system will promote economic growth. As presented, [17], a change in the financial system led to the emergence of microfinance, and that Ethics is an important aspect of Micro Finance.

Many Researchers have presented views on what the causes of loan default are. Some view only Socio-Economic causes of the borrower, and others view the credit Agency management factors. This research work presents finding on the Unethical Business Practices that causes loan default.

\section{Contextual Frame Work}

A study on conceptual framework does define this concept as an illustration of what you may find out throughout the research [18]. Further, [18] defines relevant variables in the 
study and maps out how they might relate to each other. In this study, the dependent variable is loan default, and the independent variables are lender's attitudes and borrower's attitude.

\section{Description of Variables}

\section{Lenders Attitude}

1. Portfolio Diversion.

2. Bribes for loan approval.

3. Demand for compensation for a loan received.

4. Conflict of Interest for loan administration.

5. Multiple lending.

6. Poor attention to work.

\section{Borrowers Attitude}

1. Loan diversion.

2. Initiators of bribes for loan approval.

3. False information to acquire loan.

4. Unwillingness to do timely repayment.

5. Unwillingness to do full repayment.

6. Total dishonesty of borrowers.

7. Multiple borrowing.

\section{Loan Default}

1. Number of borrowers who do not pay on time.

2. Number of borrowers who do not pay completely.

3. Number of borrowers proved to be totally dishonest.

4. Number of field Workers who falsely report default.

5. Number of missing borrowers.

The regression model will be as stated below,

$\mathrm{LD}=\beta_{0+} \beta \mathrm{l}_{1}+\beta \mathrm{b}_{2}$

Where LD - Loan Default

$\mathrm{B}_{0}$ - constant Term

$\mathrm{B}_{1}$ - Borrowers Attitude

$\beta$ - Lenders Attitude

\section{Research Methodology}

Research methodology simply shows the method to adopt in doing the research work. A study defines research methodology as a systematic method to resolve a research problem through data collection, interpretation, and drawing reasonable and valid conclusions [19].

This relates the method used to the research work. Such includes the design of research, source of data collection, and framework of analysis. The study shall incorporate the structured approach. It shall use both qualitative and quantitative techniques of research and may absorb both present and historical data in the field of research.

\section{Study Area}

Port Loko City is the district headquarter town of the Port Loko District. It has eleven chiefdoms. The district administrative activities are done in Port Loko City. The town is large in Population. The inhabitants are mainly of the Theme tribe, although there are other tribes inhabiting the town.

Occupationally, the people are petty traders and some of the agriculture sector. Some are in other services, but all contribute towards the development of the district. There schools and Institution of higher learning. The people belong to a different faith and socially interact with themselves.

\section{Study Population}

This population relates to owners of smallscale businesses in Sierra Leone. The population includes both men and women within the Pot Loko Municipality. The components of the population were: Stall owners, Hawkers, shop owner's peddlers, and other business clients of Microfinance and credit organizations in Port Loko Municipality. Major Key Players in the Microfinance Institutions in the Municipality under study are:
1. BRAC
2. LAPPO
3. ASA 


\section{Population Size}

The population size shall be four hundred respondents.

\section{Sampling Method}

The sampling method is the random sampling method. In this case, the researcher shall collect a sample from respondents of Credit organizations and Business owners randomly.

\section{Sample Size}

The sample size shall be a total number of two hundred respondents.

\section{Data Collection Method}

\section{Primary Research}

A structured and constructive questionnaire shall be administered to collect data from marketplaces, shops, and offices. This is referred to as first-hand data for processing.

\section{Secondary Research}

This relates to data reflecting the views of other writers. It is referred to as a second-hand information application for use in further research or development activity.

\section{Design of Questionnaire}

A questionnaire will be the main tool to collect the pertinent data from the selected 200 respondents. The questionnaire includes information regarding the unethical attitude of Borrowers and Lenders that causes loan default in Port Loko Municipality.

\section{Administration of Questionnaire}

A designed questionnaire will be circulated among various research experts for a critical view of content before administering to the population under study.

\section{Reasons For Selection of Tools}

The use of designed questionnaires is needful for such studies because it will gather first-hand information from respondents with regard the studies. Their opinion with regards to the studies will avail meaningful data for application and decision making. Also, the secondary data will help avail information from other researchers that will aid the studies. Finally, to do a better analysis of data for decision making, the statistical package for social sciences shall be used to aid the process.

\section{Framework Analysis}

Data will be analyzed and valid conclusions and influences drawn by using the statistical package for social sciences (SPSS). Statistical tools Applied to draw effective data analysis and to validate the variables used for analysis, following statistical tools are applied: i) Percentage Analysis, ii) Analysis of correlation by use of the Pearson Correlation. iii. Analysis of coefficient iv) Analysis of Model summary v) Analysis of Anova

\section{Findings and Discussions}

This section of the research work shows the statistical presentation and analysis of the research work.

Table 1. Showing Descriptive Statistics

\begin{tabular}{|l|l|l|l|}
\hline Descriptive Statistics & Mean & Std. Deviation & N \\
\hline Default & 81.67 & 32.427 & 12 \\
\hline Borrowers & 68.75 & 49.549 & 12 \\
\hline Lenders & 57.50 & 41.806 & 12 \\
\hline
\end{tabular}

The mean of the distribution of data for loan default (81.67) is higher than that of borrower's unethical behavior (68.75) and lenders (57.50). Amongst the independent variables, the borrower's attitude has a higher mean compared to the lender's attitude. This means that data distribution of borrowers is spread out compared to data for lenders, and the distribution of data of loan default is spread compared to borrowers and lenders. The 
standard variation of Borrowers (49.549) is higher than the lenders (41.806) and loan default (32.427). Therefore, data of borrower's attitude is spread out over a large range of values, While the standard variation of loan default indicates that the data points tend to be close to the mean.

Table 2. Table showing Opinions about the Borrower's Attitude

\begin{tabular}{|l|l|l|l|l|l|l|}
\hline & & SA & $\mathbf{A}$ & $\mathbf{N}$ & $\mathbf{D}$ & SD \\
\cline { 3 - 8 } No & Opinion & $\mathbf{\%}$ & $\mathbf{\%}$ & $\mathbf{\%}$ & $\mathbf{\%}$ & $\mathbf{\%}$ \\
\hline 1 & Loan collected was fully used for business purpose & 60 & 20 & 5 & 12.5 & 2.5 \\
\hline 2 & Gave some money to Loan officers for help & 10 & 7.5 & 40 & 22.5 & 20 \\
\hline 3 & Information given to get loan were totally correct & 50 & 25 & 10 & 5 & 10 \\
\hline 4 & I have loan from other sources for business purpose & 60 & 5 & 15 & 15 & 5 \\
\hline 5 & Do you actually have a business & 50 & 20 & 5 & 10 & 15 \\
\hline 6 & do you pay on time & 45 & 10 & 10 & 20 & 15 \\
\hline 7 & will you repay all loan money as required & 50 & 25 & 15 & 2.5 & 7.5 \\
\hline
\end{tabular}

Source: Field 2021

The Likert Scale was used to measure attitudes directly. In the study of [20], the Likert Scale is seen to be widely used since 1932, and it use is to measure attitudes. Using the Likert Scale, the opinion of the respondent with regards to the borrower's attitude was determined.

From the table above, $60 \%$ of the respondent were of the opinion that loan collected from credit organizations were used fully for business purposes. However, the remaining percentage proves that there is loan diversion amongst borrowers. This goes against the terms of the contract and hence proves some elements of borrowers to be dishonest in their dealing. This practice is said to be unethical and has a very strong influence on loan default.
$17.5 \%$ accounted for borrowers who give money to loan officers for a loan. This is what is known as bribery, and it is an unethical practice that also influences loan default.

$75 \%$ relates to a borrower who did not disclose adequate information to loan officers for a loan. They presented lies for loan acquisition. This is also unethical and influences loan default. $65 \%$ dealt with multiple loans, $70 \%$ had businesses, and the remaining of the population never had business. 55\% consented to pay on time, and the remaining population accounted for default. Finally, 75\% accounted for those who consented to do full repayment. It is conclusive form data that their borrowers that have got unethical practices that influence loan default.

Table 3. Table showing Opinion about the Lenders Attitude

\begin{tabular}{|l|l|l|l|l|l|l|}
\hline & & SA & A & N & D & SD \\
\cline { 3 - 7 } No & Opinion & $\mathbf{\%}$ & $\mathbf{\%}$ & $\mathbf{\%}$ & $\mathbf{\%}$ & $\boldsymbol{\%}$ \\
\hline 1 & Awareness of people collecting loan money for officers & 30 & 10 & 25 & 15 & 20 \\
\hline 2 & Awareness of Loan officers taken bribe for Loan approval & 40 & 20 & 15 & 5 & 20 \\
\hline 3 & Loan officers demand for thank you purse & 65 & 25 & 2.5 & 5 & 2.5 \\
\hline 4 & Are Loans given to people who are not eligible & 50 & 25 & 5 & 15 & 5 \\
\hline 5 & Are Loans given to those who have other loans & 60 & 10 & 5 & 15 & 5 \\
\hline 6 & Do loan officers visit your business for guidance & 5 & 5 & 5 & 15 & 70 \\
\hline
\end{tabular}

Source: Field Work 2021 
Lenders attitude also influences loan default. It is opinioned from respondents that $40 \%$ accounts for awareness for people collecting loan for Loan officers. This is what is known as portfolio diversion. $60 \%$ relates to an opinion of loan officers taking bribes for loan approval of clients. On the other hand, 90 viewed of a thank you purse for loan approved and disburse.

$75 \%$ had an opinion that loan is granted to those who are illegible. If this opinion stands to be true, then there are little or no screening activities done before disbursement of loan. $70 \%$ also account for multiple loans disbursement. $10 \%$ accounts for the guidance of clients by loan officers. There is total neglect on monitoring of borrowers for guidance. Lenders are also opinioned to be unethical in some practices, which may influence loan default.

Table 4. Table Showing Opinion about Loan Default

\begin{tabular}{|c|c|c|c|c|c|c|}
\hline \multirow[b]{2}{*}{ No } & \multirow[b]{2}{*}{ Opinion } & $\mathbf{S A}$ & $\mathbf{A}$ & $\mathbf{N}$ & D & SD \\
\hline & & $\%$ & $\%$ & $\%$ & $\%$ & $\%$ \\
\hline 1 & Awareness of borrowers who do not pay on time & 60 & 30 & 10 & - & - \\
\hline 2 & awareness of borrowers who do not pay in full & 50 & 25 & 2.5 & 12.5 & 10 \\
\hline 3 & Awareness of borrowers who are totally dishonest & 50 & 30 & 10 & 7.5 & 2.5 \\
\hline 4 & Awareness of dishonest Loan officers & 55 & 30 & 5 & 10 & - \\
\hline 5 & Awareness of abscond loan officers & 45 & 25 & 15 & 15 & - \\
\hline 6 & Awareness of Abscond borrowers & 70 & 20 & 10 & - & - \\
\hline
\end{tabular}

Source: Field work 2021.

From the analysis above $90 \%$ shows awareness of borrowers who do not pay on time. Payment not done on time makes the loan default. $75 \%$ shows awareness of respondents with regards to borrowers who do not pay in full, $80 \%$ shows unawareness of borrowers who are totally dishonest. $85 \%$ accounts for awareness of loan officers that are totally dishonest. $70 \%$ and $90 \%$ expressed awareness for the absconding of Loan officers and Borrowers respectively. All these unethical practices account for Loan default amongst small-scale Enterprises in the Municipality of Port Loko - Sierra Leone.

Table 5. Table showing Pearson Correlation

\begin{tabular}{|l|l|l|l|l|}
\hline Correlations & & Default & Borrowers & Lenders \\
\hline \multirow{4}{*}{ Pearson Correlation } & Default & 1.000 & .530 & .379 \\
\cline { 2 - 5 } & Borrowers & .530 & 1.000 & .424 \\
\cline { 2 - 5 } Sig. (1-tailed) & Lenders & .379 & .424 & 1.000 \\
\hline \multirow{4}{*}{$\mathbf{N}$} & Default & & .038 & .112 \\
\cline { 2 - 5 } & Borrowers & .038 & & .085 \\
\cline { 2 - 5 } & Lenders & .112 & .085 & \\
\hline & Default & 12 & 12 & 12 \\
\cline { 2 - 5 } & Borrowers & 12 & 12 & 12 \\
\cline { 2 - 5 } & Lenders & 12 & 12 & 12 \\
\hline
\end{tabular}

The Pearson correlation table shows the relationship of the variables under study and their level of significance.

The correlations result of Borrowers Unethical practices and Lenders unethical practices were seen to be positive and responded to the Hypothesis of the study of the review of the Unethical business Practices that causes loan default in small scale businesses in Pot Loko Municipality. 


\section{H1 - There are Lenders Attitudes that Influences Loan Default}

The Pearson correlation is used to determine the degree of relationship between the variables. From Statistical Package analysis, there is a positive relationship of Lender's attitude towards loan default in small-scale businesses in the Port Loko Municipality. Depiction from the table shows that when the attitude of |Lenders has a degree relationship of 1 there is also a degree of relationship of .379 defaults, with a level of significance of .112. Hence the hypothesis which states that Lender's attitudes influence loan default is accepted. The opinion of bribe acceptance, request for thank you purse after loan disbursement, Portfolio diversion, given of loan to ineligible people, loan duplication, and poor supervision greatly influences loan default in small-scale enterprises in Port Loko Municipality.

\section{H2- There are Borrowers Attitudes that influences Loan Default}

The degree of the relationship shown by the Pearson correlation for Borrower's attitude of 1 has a relationship of .530 on the loan default and a positive level of significance of .38 on the default as opinioned by the respondents. This shows that there are borrower's attitudes that influence loan default, and hence we accept the Hypothesis. Opinion of respondents proved that there are Borrower's unethical practices that influence loan default. Unethical practices like loan diversion, bribery, loan duplication unwillingness to do repayment all influences loan default in small scale businesses in Port Loko Municipality.

Table 6. Table showing Model Summary

\begin{tabular}{|l|l|l|l|l|l|l|l|l|l|}
\hline \multicolumn{2}{|l|}{ Model Summary } \\
\hline Model
\end{tabular}

The model summary shows multiple positive correlations with $\mathrm{R}=.557$ between the independent variables and dependent variables. Also, an $\mathrm{R}$ square $=.310$ indicating that the independent variable accounted to $31 \%$ of the total causes of loan default in small-scale enterprises in the Port Loko Municipality. This

shows the proportion of variance in the dependent variable loan default, which can be predicted from the independent variables (Borrower's attitude and Lenders Attitude). The researcher, therefore, observes that the independent variables have an influence on the dependent variables.

Table 7. Table showing the Coefficient

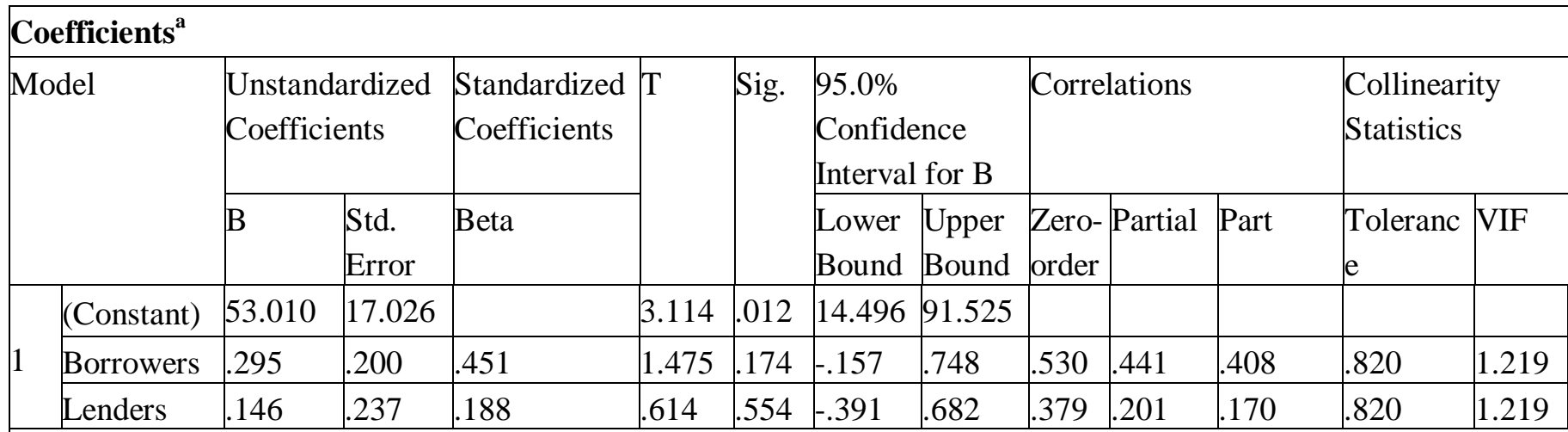

a. Dependent Variable: Default 
From the model coefficient table, the following mathematical model was derived:

$\mathrm{Y}=53.010+.295 \mathrm{X}_{1}+.146 \mathrm{X}_{2}$. From the derived regression model with all other factors remaining the same, Unethical business practices causing loan default had a constant of
53.010. $\beta$.295, with a significance level of 0.174 , shows how loan default could be explained by the attitude of the borrowers. In addition, $\beta 0.146$ with a significance level of 0.554 shows how loan default could be explained by the attitude of the Lenders.

Table 8. Showing ANOVA

\begin{tabular}{|c|c|c|c|c|c|}
\hline \multicolumn{6}{|l|}{ ANOVA $^{\mathrm{a}}$} \\
\hline Model & Sum of Squares & Df & Mean Square & $\mathbf{F}$ & Sig. \\
\hline Regression & 3588.706 & 2 & 1794.353 & 2.024 & $.188^{\mathrm{b}}$ \\
\hline Residual & 7977.961 & 9 & 886.440 & & \\
\hline Total & 11566.667 & 11 & & & \\
\hline \multicolumn{6}{|c|}{ a. Dependent Variable: Default } \\
\hline \multicolumn{6}{|c|}{ b. Predictors: (Constant), Lenders, Borrowers } \\
\hline
\end{tabular}

Anova statistically proves a regression sum square of 3588.706, a mean square of 1794.353 F-statistics at 2.024 with a significant level of .188. This shows that the Lenders Unethical business Practice, Borrowers Unethical Business Practice, and Loan default as group variables are jointly significant. From the Anova, we can conclude from the regression that the variables fit the studies on loan default.

\section{Discussion of Finding}

From the presentations above, it is clear to note that there are unethical practices in the field of credit operation in the Port Loko Municipality. There are borrower's unethical practices and lender's unethical practices all staging loan default in the loan management. These defaults, however have an adverse effect on the going concern of small-scale enterprises in the Port Loko Municipality.

\section{Conclusions and Recommendations}

\section{Conclusions}

Studies have been made on the causes of loan default. Some of these studies viewed unethical issues as a subset of their variables. This studies however, makes thorough research and presentation on the review of the unethical business practices that influence loan default in small scale businesses in Port Loko Municipality. From the studies, it is evident that
Unethical business practices influence Loan default. The Borrower and the Lenders attitude are the independent variables of the dependent variables loan default. The attitude of both the borrowers and lenders were opinioned to have a positive significance on loan default.

\section{Recommendation}

Unethical practices hinder the growth of both the credit agency and the borrower. It is fitting that credit agencies monitor their field workers as they get to the field to do screening for disbursement. Management should ensure that they are partners in the fieldwork. These unethical issues in the field are opinioned to be done by the field worker.

Management should ensure proper screening before disbursement. Incidence of loan and portfolio diversion happens when there is no close supervision of work. The issue of bribery amongst clients and field workers should be monitored. However, the pay slip of a Credit worker for the month of March and April 2021 shows a discouraging monthly salary. This does permit decent workers to take bribes and embark on unethical practices. Management must ensure an increase in pay and work on an improved condition of service for their workers to minimize the rate of unethical practices in the field of Credit implementation. If unethical issues are addressed by credit firms, the issue of 
the borrower's unethical practices will be minimized, and hence there will be a minimized loan default in operations.

\section{Conflict of Interest}

Management seeks for more clients for disbursement to get returns on their investment. For them, the more the clients, the more the profitability. This has prompted credit disbursement to illegible people. This kicks against ethical practices of implementation. The borrowers are not much interested in repayment of loans but getting cash to meet their obligations. Both conflicts of interest lead to loan default.

\section{References}

[1] Luis A. Aguilar (2021), Effective small business capital formation - Harvard law school forum for corporate governance Publication.

[2] Brian Barnier (2021), definition of capital Article on Capital - Investopedia publications.

[3] Editorial team (2019), fourteen sources of fund for private businesses - Entrepreneur handbook https://entrepreneurhandbook.co.uk-sources-offunds.

[4] Leon Teeboom (2019), Role of Micro Finance Institutions - Chron Publications

https://smallbusiness.chron.com-role-microfinanceins.

[5] Brau, James C.; Woller, Gary M. (2004), Micro Finance -Microfinance: A comprehensive review of the existing literature.

[6] Julia Kagn (2020), definition of Collateral Loan Basics - Investopedia https://www.investopedia.com/terms/c/collateral.asp

[7] Parlex Financial Dictionary (2012), Definition of Loan Portfolio - $\quad$ https://financialdictionary.thefreedictionary.com/loan+portfolio.

[8] Alexanra Twin (2021), Business Ethics Business Essentials

https://www.investopedia.com/terms/b/businessethics.asp.

\section{Acknowledgement}

I write to thank God for His supreme power and enlightenment to carry out this research work. The effort of all participants in the brainstorming activity is highly appreciated.

My supervisor Professor Dr. Saranya Anthony, did very well in constructively criticizing this manuscript to its reality. She deserves a thank you and blessings for duty mastered by her.

May I finally submit applause for all those who, in diverse ways, contribute towards this manuscript. May God bless all, including my wife, Children, Family members, and Friends.

[9] James Chen (2021), - Definition of Investor Trading skills and essentials https://www.investopedia.com/terms/i/investor.asp. [10] Valon Lluka (2010), Business Ethics defined file:///C:/Users/PASTOR/AppData/Local/Temp/Busi ness_Ethics_Some_Theoretical_Issues.pdf.

[11] Financial Accounting Standard Board (2014), Definition of Going Concern-Financial Accounting Series - Presentation of Financial Statements Going Concern (Subtopic 205-40) - https://www.fasb.orgccurl-ASU2014-15.

[12]Bankers Club (2020), diversion of fund Diversion and Siphoning of fund http://bankersclub.in/diversion-of-funds-andsiphoning-of-funds/.

[13] Skender Gojani (2015), Loan Agreement European Academic Research Vol. II, Issue 11/ February 2015.

[14] Rosemary Carlson (2021), what is loan default The Balance Publication

https://www.thebalance.com/what-does-it-mean-todefault-on-a-loan-4684116.

[15]Laura Holton- Definitions of unethical business practices - The ugly truth about Unethical Business Practices - https://myva360.com/blog/the-ugly-truthabout-unethical-business-practices.

[16] Kristy Anjala (2018), Unethical Behaviour of Credit officers - Bad target, Bad loan and Bad 
Behaviour - An Enquiry into Micro Credit Loan Officers in Sri Lanka.

[17] Reinhard H. Schmidt, Ethics in Micro Finance https://www.bbvaopenmind.com/en/articles/ethicsin-microfinance/.

[18]Bas Swaen (2021), definition of conceptual framework- constructing a conceptual frameworkhttps://www.scribbr.com/dissertation/conceptualframework/.
[19] Imed Bouchrika (2021), - definition of research methodology - How to Write Research Methodology: Overview, Tips, and Techniques Guide 2 Research.

[20] Mcleod (2019), Likert Scale -Simply psychology

https://www.simplypsychology.org/likert-scale.html. 